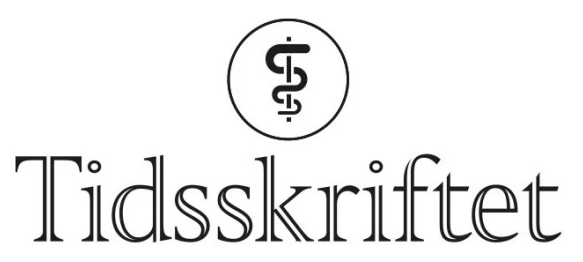

DEN NORSKE LEGEFORENING

\title{
Metodevurdering av medisinsk utstyr
}

\author{
KOMMENTAR \\ KJETIL G. BRURBERG \\ kjbr@fhi.no \\ Kjetil G. Brurberg er avdelingsdirektør i Folkehelseinstituttet.
}

\section{MARTIN LERNER}

KÅRE BIRGER HAGEN

TRYGVE OTTERSEN

Ingen av forfatterne har oppgitt noen interessekonflikter.

Vi vil takke Øian med flere som i en velskrevet kronikk diskuterer behovet for kritisk refleksjon når man tar i bruk nytt medisinsk utstyr (1). Forfatterne advarer mot å lese CEmerking som en godkjenning av at effekt og risiko er tilfredsstillende dokumentert, og viser at en villet og trygg innføring av nytt medisinsk utstyr fordrer vurderingsmekanismer utover de regulatoriske. Vi deler kronikkforfatternes syn, og vil fremheve at det allerede finnes et system som kan bidra til å fylle det behovet som kronikkforfatterne peker på.

I Nye metoder (et felles system for å beslutte hvilke metoder som skal tilbys i spesialisthelsetjenesten) er det allerede et system for å vurdere medisinsk utstyr før innføring, og vi mener det er gode grunner til å bygge videre på eksisterende systemer fremfor å etablere nye. Det eksisterende systemet har imidlertid stort potensiale for videreutvikling. En av de utfordringene vi står overfor handler om å etablere gode rutiner for hva slags utstyr som skal evalueres og ordninger som sikrer at beslutninger om innføring av utstyr følges opp.

Nytt medisinsk utstyr og forbedrede versjoner av eksisterende utstyr introduseres i stort tempo, og det er i praksis umulig å evaluere alt nytt utstyr før det introduseres på markedet. Bestillerforum for Nye metoder sitter i dag med ansvar for å prioritere hvilket utstyr Folkehelseinstituttet skal vurdere og hvor omfattende metodevurderingene skal være. En metodevurdering («health technology assessment» (HTA)) skal danne grunnlag for en påfølgende beslutningsprosess, og er en systematisk vurdering av forskning om effekt og sikkerhet av tiltak. De fleste metodevurderinger inneholder også en vurdering av $\emptyset$ konomiske, etiske, sosiale, organisatoriske eller juridiske konsekvenser. 
Kriteriene for hva slags utstyr som skal metodevurderes har vært uklare, men våren 2021 etableres det er prosjekt om medisinsk utstyr og kriterier ledet av Sekretariatet for Nye metoder. Prosjektet er planlagt med bred deltakelse med representanter fra kliniske miljøer, industrien, forvaltningen og brukere. Tydeligere kriterier for hva slags utstyr som skal vurderes på hvilket nivå (lokalt, regionalt eller nasjonalt) vil bidra til bedre forutsigbarhet for Folkehelseinstituttets metodevarslingsfunksjon og for andre aktører som kan foreslå utstyr for metodevurdering via hjemmesidene til Nye metoder. Et velfungerende system avhenger av innspill og forslag fra fagmiljøer som har god kunnskap om hvilke metoder som er på vei inn.

Etter at metodevurdering er gjennomført skal Beslutningsforum for Nye metoder ta stilling til om utstyret kan introduseres. I tilfeller der kunnskapsgrunnlaget er begrenset kan Beslutningsforum gå inn for betinget innføring som forutsetter bruk av kvalitetsregistre som kan informere revurdering etter en viss tid. Det er viktig å jobbe videre med å sikre at beslutninger følges opp, og at utstyr som er metodevurdert blir enklere å innføre enn tilsvarende utstyr som ikke er metodevurdert.

\section{LITTERATUR}

1. Øian P, Grammeltvedt E, Iversen OE et al. Etablering av behandlingsmetoder uten kritisk refleksjon. Tidsskr Nor Legeforen 2021; 141. doi: 10.4045/tidsskr.20.0917. [PubMed][CrossRef]

Publisert: 25. mai 2021. Tidsskr Nor Legeforen. DOI: 10.4045/tidsskr.21.0347

(C) Tidsskrift for Den norske legeforening 2023. Lastet ned fra tidsskriftet.no 26. april 2023. 